\title{
ЕКСПЕРТНЕ ОЦІНЮВАННЯ У ВИЗНАЧЕННІ ЕФЕКТИВНОСТІ ЛІКАРСЬКИХ ЗАСОБIB
}

\author{
Л. Ю. Бабінцева \\ Національна медична академія післядипломної освіти імені П. Л. Шупика
}

\begin{abstract}
Проаналізовано питання застосування методу «Дельфі» для кількісного оцінювання близькості ефекту впливу оригінального лікарського засобу та генерика. Запропонована група коригуючих коефіцієнтів для наближення методики експертного оцінювання ді лікарських засобів до особливостей складного, але вельми необхідного для практично охорони здоров'я процесу х вибору.
\end{abstract}

Ключові слова: ефективність генериків і оригінальних лікарських засобів, метод експертних оцінок, метод «Дельфі», коригувальні коефіцієнти.

\section{ЭКСПЕРТНЫЕ ОЦЕНКИ В ОПРЕДЕЛЕНИИ ЭФФЕКТИВНОСТИ ЛЕКАРСТВЕННЫХ СРЕДСТВ}

\author{
Л. Ю. Бабинцева \\ Национальная медицинская академия последипломного образования \\ имени П. Л. Шупика
}

\begin{abstract}
Рассмотрены вопросы разработки методологии сопоставления эффективности действия оригинальных лекарственных средств и генериков. Использованы классические идеи метода «Делфи». Однако в процедуру определения эффективности препарата внесены новые коэффициенты. Прежде всего, в качестве показателя компетентности эксперта предложен коэффициент его компетентности и коэффициент степени ознакомления эксперта с обсуждаемой проблемой. Также предложен коэффициент расхождения мнений экспертов, обусловленный неодинаковым опытом применения лекарственного средства, частотой нежелательных эффектов препарата, связанной с индивидуальной непереносимостью и устойчивостью действия препарата. Еще одной инновацией подхода считаем кластеризацию экспертов по опыту работы с конкретными препаратами. Предполагается, что применение методики может быть полезным в определении стратегии программ лечения основных заболеваний и травм.
\end{abstract}

Ключевые слова: эффективность генериков и оригинальных лекарственных средств, метод экспертных оценок, метод «Делфи», корригирующие коэффициенты.

\section{EXPERT ASSESSMENT TO DETERMINE THE DRUGS EFFECTIVENESS}

\author{
L. Yu. Babintseva \\ National Medical Academy of Postgraduate Education by P. L. Shupyk
}

The article analyzes the use of the method "Delphi" to quantify the proximity of the original and the generic drug effect. It's proposed the group corrective coefficients for approximation methods of expert drug action evaluation to therapeutic drug choice. There is underlined, that this task is particularly difficult, but very necessary for practical health care.

Key words: efficacy of generic and original drugs, method of expert estimates, method "Delphi", corrective coefficients.

Вступ. Ефективність планування й управління системою лікарського забезпечення неможлива без відповідної інформаційної підтримки, що забезпечує вірність прийняття рішення на різних рівнях.

Великі зміни ситуації на фармацевтичному ринку, що відбулися за останні кілька років, поряд із позитивними ефектами, призвели до дефіциту повної і достовірної інформації, що відображає попит на лікарські препарати. Існуюча інформація являс собою лише експертні оцінки окремих учасників ринку чи дані регуляторних органів, що включають у себе спеціалізовані показники: обсяг виробництва, обсяги операцій із ввезення або дані про державне фінансування.

(C) Л. Ю. Бабінцева 
Сьогодні особливо актуальними та вкрай необхідними $€$ питання ціноутворення при оптимальних витратах для збереження і покращення тривалості життя. Враховуючи активну динаміку фармацевтичного ринку такий аналіз повинен бути постійним у всіх медичних закладах.

Зауважимо, що ефективність кардіологічної допомоги і тим самим покращання рівня здоров'я населення безпосередньо залежать від максимального дотримання медичних технологій ії надання - рекомендованих стандартів обстеження та лікування хвороб системи кровообігу на всіх етапах системи охорони здоров'я.

Бурхливий розвиток медичної науки, поява сучасних технологій і оригінальних лікарських засобів (ЛЗ) дозволили підійти до вирішення проблеми артеріальної гіпертензії (АГ) з якісно нових позицій, які сприяють не тільки ефективному й адекватному зниженню рівня артеріального тиску (AT), але і зменшенню ступеня ризику розвитку ускладнень

Вивченню різних аспектів попиту і потреби в лікарських засобах присвячена достатня кількість робіт. Запропоновані методики дозволяють аналізувати окремі потреби в лікарських засобах у сегментах ринку: різних категоріях хворих, закладах охорони здоров'я, фармакотерапевтичних групах тощо. Водночас сучасні ринкові умови диктують необхідність зміни методик i змісту аналізу попиту. Очевидна необхідність виявлення інтегральних визначальних критеріїв, за допомогою яких стане можливим повноцінне проведення аналізу ринку фармацевтичних препаратів.

Мета дослідження - визначення методики зіставлення ефективності генериків і оригінальних лікарських засобів із точки зору їх лікувальних властивостей.

Матеріал і методи дослідження. Проведено дослідження фармацевтичногоринку України на прикладі зіставлення фармацевтичної дії генериків і оригінальних лікарських засобів, що застосовуються для лікування гіпертонічної хвороби (ГХ) І та ІІ ступенів. Дані отримано з амбулаторних карт та історій хвороб пацієнтів із документованою ГХ, які отримують спостереження в повсякденній клінічній практиці (заклади первинної медико-санітарної допомоги м. Києва).

Для досягнення мети дослідження як основний використано метод (Дельфі). Хоча він $є$ одним із найпоширеніших методів експертного прогнозування, останнім часом його почали широко застосовувати для узагальнення думок окремих експертів в узгоджену групову думку, що значно підвищує гнучкість, швидкість і точність прогнозування. По- ширенню методу сприяли такі особливості: анонімність експертів (об'єкти-учасники експертної групи невідомі один одному); використання результатів попереднього туру опитування (фахівець, який проводив дослідження за методом “Дельфі", витягує з анкет тільки ту інформацію, яка стосується даної проблеми та враховує думки експертів (за)» $\mathrm{i}$ (проти») по кожній точці зору); статистична характеристика групової відповіді (використовуються статистичні характеристики відповіді, що включає думку всієї групи. Кожна відповідь всередині групи враховується при побудові медіани, а величина розкиду відповідей характеризується величиною інтервалу між квартилями. Іншими словами, групова відповідь може бути представлена у вигляді медіани і двох квартилів).

Результати й обговорення. В охороні здоров'я важливим $\epsilon$ не тільки забезпечення належної медичної допомоги, а й економічне обгрунтування, тобто фармакоекономічний аналіз. Серед визначальних питань зіставлення ЛЗ із однією й тією ж діючою речовиною виділяються проблеми загального використання генериків, оцінювання їх ефективності, обгрунтування попиту на них тощо

Технологічно метод «Дельфі» у вирішенні поставленого завдання реалізується шляхом виконання ряду процедур.

За допомогою методів математичної статистики отримували узагальнену думку експертів. Узгодженість у думках експертів здійснювалася за допомогою коефіцієнта конкордації. Ми використовували коефіцієнт конкордації Кендала $(K)$. Як і при класичному підході, коефіцієнт $K$ може приймати значення в межах від 0 до 1. При повній узгодженості думок експертів коефіцієнт конкордації дорівнює одиниці, при повній незгоді - нулю. Визначався середній ранг, середнє статистичне значення близькості $j$-го генерика по дії відносно брендового препаpaty $S_{f}$ :

$$
S_{j}=\sum_{i=1}^{m_{i}} S_{i j} / m,
$$

де $m$ - кількість експертів, які оцінюють близькість ефекту $j$-го генерика порівняно з оригінальним ЛЗ;

$i$ - порядковий номер експерта; $i=1,2, \ldots, m$;

$j$ - порядковий номер генерика, $j=1,2, \ldots, n$.

Чим більша величина $S_{p}$ тим ефективніша дія Л3.

Оцінювали середній ранг кожного генерика за формулою:

$$
\bar{S}=\sum_{j=1}^{n} S_{j} / n
$$


У групі ЛЗ із однією діючою речовиною послідовно обчислювали відхилення $d_{j}$ середнього рангу $j$-го генерика від середнього рангу сукупності:

$$
d_{j}=S_{j}-\bar{S} .
$$

Суттєвою відмінністю методики, що пропонується в роботі, є використання коригуючих коефіцієнтів $R_{k}$. Відзначимо, що в даний час багатьма дослідниками в експертних процедурах пропонуються коригуючі коефіцієнти $-R_{k}$. Серед яких коефіцієнт компетентності експерта $\left(R_{1}\right)$; коефіцієнт ступеня ознайомлення експерта 3 проблемою, що обговорюється $\left(R_{2}\right)$; коефіцієнт аргументованості, що враховує структуру аргументів, які послужили експерту підставою для певної оцінки $\left(R_{3}\right)$.

Проте, на наш погляд, застосування одного коригуючого коефіціснта не може забезпечити валідність оцінювання близькості генерика по дії до орендованого препарату. Справа в тому, що ранжування лікарського засобу експертом може дати надійні результати, якщо останній має однаковий досвід застосування всіх ЛЗ, що зіставляються. На практиці подібні випадки досить рідкісні. Це означає, що ранжування дії різних генериків у різних експертів дає зміщену оцінку.

Для вирівнювання отриманих даних ми запропонували процедуру зіставлення експертних висновків методом кластеризації фахівців із досвіду роботи 3 групами препаратів. Іншими словами, вибираються кілька груп експертів: 1. Група, яка працювала 35 i більше Л3; 2. Група, яка працювала з 2-4 Л3; 3. Група експертів, яка дослідила дію одного 3 генериків. За даними оцінок ефективності препарату в трьох групах експертів обирається коефіцієнт розбіжності думок $R_{4}\left(0<R_{4}<1\right)$.

Необхідно врахувати також те, що вибір лікарського засобу здійснюеться тільки на основі знання його клініко-фармакологічної характеристики. Проте $\epsilon$ ще й показники індивідуальної переносимості лікарсько-

\section{Література}

1. Багирова В. Л. Определение направлений исследований по экономике фармации на основе наукометрических методов / В. Л. Багирова, О. А. Иванова, Е. М. Терентьева // Ремедиум. - 2003. - № 7-8. - С. 14-16.

2. Егоров В. А. Характеристика номенклатуры сердечнососудистых препаратов фармацевтического рынка России / [Егоров В. А., Мошкова Л. В., Куркин В. А. и др.] // Фармация. -2002 . - № 4. - С. 19-21.

3. Кононова С. В. Факторы фармацевтического рынка / С. В. Кононова // Новая Аптека. - 2002. - № 2. - С. 13-17. 4. Федоренко І. А. Оцінка потенціалу фармацевтичного ринку регіонів України // Сборник научных трудов "Вест- го засобу та стійкості дії. Ці приклади показують, що, крім фармакокінетичних методів лікар повинен знати всі можливі фармакологічні ефекти і прояви небажаних реакцій, а з них особливо ті, що $є$ головними ознаками ефективності та побічної дії препарату.

Видається дуже важливим облік небажаних дій генерика в зіставленні з оригінальним препаратом із застосуванням коефіціснта $\left(1-R_{5}\right)$, причому $\left(0<R_{5}<1\right)$.

Визначимо тепер загальний коригуючий коефіцієнт $\left(\mathrm{R}^{*}\right)$, що дорівнює добутку значень чотирьох попередньо визначених поправок на компетентність експертів, іх аргументованості, ступінь розбіжності думок і коефіцієнт небажаних ефектів:

$$
R^{*}=\prod_{k=1}^{t} R_{1} R_{2} R_{3} \ldots R_{k},
$$

де $k$ - порядковий номер корегуючого коефіціснта; $t$ - кількість коригуючих коефіцієнтів.

Отже, ефективність генерика по відношенню до оригінального ЛЗ дорівнює:

$$
S_{j}^{*}=R^{*} \cdot S_{j} .
$$

Зрозуміло, запропонований підхід не в усіх випадках буде абсолютно інформативним; крім того, він не єдиний, досить складний, вимагає підготовленого медичного та технічного персоналу, насамперед наявності експертів. Проте в ряді принципових випадків цей підхід може бути вельми корисним.

Висновки. 1. Запропоновано методику зіставлення фармацевтичної дії генериків і оригінальних лікарських засобів. Методика заснована на модифікованому експертному оцінюванні з використанням ряду нових коефіціснтів - проблемного розходження думок експертів, частоти небажаних ефектів ЛЗ, що пов'язано з індивідуальною непереносимістю та стійкістю дії засобу тощо.

2. Застосування методики може бути корисним при визначенні стратегії програм лікування основних захворювань і травм.

ник НТУ "ХПИ" : Технічний прогрес та ефективність виробництва. -2010. -№ 8. - С. 187-191.

5. Решетников А. В. Технология медико-социологического исследования в социальной системе / А. В. Решетников. -М. : ММА им. И.М.Сеченова, 2000. -210 с.

6. Мнушко 3. М. Менеджмент та маркетинг у фармації. Ч. ІІ. Маркетинг у фармації : підруч. для студ. ВНЗ. - 2-ге вид., доп. та перероб. / З. М. Мнушко, Н. М. Діхтярьова ; за ред. З. М. Мнушко. - Х. : Вид-во НФаУ; Золоті сторінки, 2010. $-512 \mathrm{c}$ 